\title{
Asia Pacific Report: A New Zealand Nonprofit Journalism Model for Campus-Based Social Justice Media
}

\author{
David Robie ${ }^{1}$
}

\begin{abstract}
For nine years, the Pacific Media Centre research and publication unit at Auckland University of Technology has published journalism with an 'activist' edge to its style of reportage raising issues of social justice in New Zealand's regional backyard. It has achieved this through partnerships with progressive sections of news media and a nonprofit model of critical and challenging assignments for postgraduate students in the context of coups, civil war, climate change, human rights, sustainable development and neo-colonialism. An earlier Pacific Scoop venture (2009-2015) has morphed into an innovative venture for the digital era, Asia Pacific Report (APR) (http://asiapacificreport.nz/), launched in January 2016. Amid the current global climate of controversy over 'fake news' and a 'war on truth' and declining credibility among some mainstream media, the APR project has demonstrated on many occasions the value of independent niche media questioning and challenging mainstream agendas. In this article, a series of case studies examines how the collective experience of citizen journalism, digital engagement and an innovative public empowerment journalism course can develop a unique online publication. The article traverses some of the region's thorny political and social issues-including the controversial police shootings of students in Papua New Guinea in June 2016.
\end{abstract}

Keywords: Alternative Media, Campus Media, Citizen Journalism, Digital Engagement, Independent Journalism

\footnotetext{
1 Professor of Journalism and Communication Studies and Director of the Pacific Media Centre in the School of Communication Studies, Auckland University of Technology, New Zealand. He is also the founding editor of the Pacific Journalism Review research journal, editor of Asia Pacific Report and convener of the Pacific Media Watch freedom project. He is the author of several media and politics books, including Mekim Nius: South Pacific Media, Politics and Education (University of the South Pacific, 2004) and Don't Spoil My Beautiful Face: Media, Mayhem and Human Rights in the Pacific (Little Island Press, 2014). Co-winner of the 2015 AMIC Asian Communicators Award, he was a participant in the World Class Professor (WCP) program in partnership with CESASS, Universitas Gadjah Mada. Corresponding e-mail: david.robie@aut.ac.nz
} 


\section{David Robie}

\section{Introduction}

One of the ironies of the digital revolution is that there is an illusion of growing freedom of expression and information in the world, when in fact often the reverse is true. These are bleak times with growing numbers of journalists being murdered with impunity, from the Philippines to Somalia and Syria. The world's worst mass killing of journalists was the so-called Maguindanao, or Ampatuan massacre (named after the town whose dynastic family ordered the killings), when 32 journalists were brutally murdered in the Philippines in November 2009 (Lingao, 2010).

But increasingly savage slayings in the name of terrorism are becoming the norm. In early August 2015, five masked jihadists armed with machetes entered the Dhaka home of a secularist blogger in Bangladesh and hacked off his head and hands while his wife was forced into a nearby room. According to the New York-based Committee to Protect Journalists, 506 journalists were killed in the decade between 2002 and 2012, almost double the 390 slain in the previous decade (Robie, 2015b). (Both Reporters Sans Frontières [RSF] and Freedom House also reported escalating death tolls and declines in media freedom in 2016). The most recent RSF report in April 2018 warned that a 'hatred of journalism' was threatening democracies, and was highly critical of China's increasingly authoritarian media influence in the Asia-Pacific region (RSF, 2018).

While there appears to be far more democracies in the world than ever before, the committee's executive director Joel Simon believes there is a sinister new threat. This is in some respects more troublesome than the old style dictatorships. Simon has described this new scourge in The New Censorship: Inside the Global Battle for Press Freedom as the 'democratators', those leaders who profess to be democratic but are actually subverting their mirage of open governance (Simon, 2015).

What are these differences between dictators and democratators? Dictators rule by force. Democratators rule by manipulation. Dictators impose their will. Democratators govern with the support of the majority. Dictators do not claim to be democrats - at least credibly. Democratators always do. Dictators control information. Democratators manage it. (Simon, 2015, p. 33)

Simon points out that democratators win elections yet while they may be free, they are not really fair, meaning they are decided by fraud (as has been widely alleged in the recent case of Papua New Guinea in June 2017) (Juffa, 2017). He has a growing list of leaders that fit this label, including Latin American 'populists' like Rafael Correa 
of Equador and Daniel Ortega of Nicaragua, 'European backsliders' like Viktor Orban of Hungary and Viktor Yanukovych, the deposed former president of Ukraine, and African leaders such as Paul Kagame of Rwanda and Jacob Zuma of South Africa. Undoubtedly, Fiji's prime minister Voreqe Bainimarama ought to be on this list too since having been elected in September 2014, ending eight years of military backed dictatorship and providing a figleaf of legitimacy while continuing to manipulate public debate and information (Robie, 2016c). Another list member could arguably be Prime Minister Peter O’Neill of Papua New Guinea. His powerbase was being tested in a general election in June 2017 general election after he had effectively seized control of the country through an unprecedented 'constitutional coup' against the incumbent, 'founding father' Sir Michael Somare, in 2011 (Pryke, 2016). Using the Committee to Protect Journalists' criteria, the Trump administration is also being condemned for the alleged 'fake news' and 'war on truth' campaign and threats against a mainstream media already suffering from perceptions of declining credibility (Kolhatkar, 2017).

Facts are the enemy of charlatans and con artists, hence Trump's adviser and campaign chair Kellyanne Conway's offer of 'alternative facts' (Bradner, 2017) in the face of real ones on the size of Inauguration Day crowds in Washington, DC. In Trump's milieu, bona fide news reports are considered 'fake news', while Conway's lies (and those of the president) are simply 'alternative facts'. (Kolhatkar, 2017)

The issues highlighted by Simon are to some degree reflected in the evolution of some journalism programmes in the Asia-Pacific region. For two decades, [the author has] been an initiator of a series of independent newspapers based in prominent South Pacific journalism programmes hosted at four universities in Australia, Fiji, New Zealand and Papua New Guinea. All of the publications have played an 'activist' role in raising issues of social justice and campaigning for more critical and challenging assignments for student media in the context of coups, civil war, climate change, development and neo-colonialism. They have been bastions of free speech and public discourse, even to the point of threatened deportation in the case of Fiji for teaching investigative journalism (Robie, 2003).

All of the publications have won awards for their brand of journalism. Starting with the University of Papua New Guinea's Uni Tavur in 1994 and the Sandline mercenary crisis, when then Prime Minister Sir Julius Chan was forced out of office, the models have progressed through Wansolwara at the University of the South Pacific 


\section{David Robie}

(award-winning coverage of the 2000 George Speight attempted coup), to Pacific Scoop for six years at Auckland University of Technology with extensive coverage of human rights violations in Fiji and West Papua. The Pacific Scoop venture has now morphed into a new and distinctive independent venture for the digital era, Asia Pacific Report (http://asiapacificreport.nz/) launched in January 2016. In this article, a series of case studies examines how the collective experience of citizen journalism, digital engagement and an innovative public empowerment journalism course based at AUT's Pacific Media Centre has developed a unique publication. This initiative engages with the evolving theory behind the publications (Robie, 2004a, 2004b, 2006, 2012, 2014c) such as reflected in Deliberative Journalism (DJ), Human Rights Journalism (HRJ) and other models (Hackett et al., 2017; Nash, 2016; Romano, 2011; Shaw, 2011).

\section{Journalism as Campus-Based Independent Publishing}

One of the most innovative journalists and media academics in the Asia-Pacific region to successfully integrate investigative journalism, journalism-as-research and independent community journalism with an academic programme is Wendy Bacon, a now retired professor of journalism at the University of Technology Sydney and former director of the Australian Centre for Independent Journalism (ACIJ). She writes for New Matilda and other independent media. In one of her earlier progressive papers critiquing twenty-five years of journalism education and research in the academy, Bacon articulated how journalism education and research had slowly won acceptance within the broader academic field but that many journalists had felt 'undervalued' within humanities or social science faculties (Bacon, 2006).

It is ironical-and a sad statement about the declining status of mainstream journalism in Australia and New Zealand-that UTS in early 2017 announced the closure of the Centre after a 'significant contribution to journalism and [as] a strong advocate for the public right to know and the role of journalism in strengthening democracy' (Spongberg, 2017). An internal UTS memorandum on March 28 to academic staff acknowledged:

In its over twenty-five-year history, ACIJ collaborated in major investigations with a wide range of media outlets and was involved in both national and international research collaborations such as the Global Environmental 
Journalism Initiative (via the Erasmus Mundus program overseen by the European Commission). (Ibid.)

Other ground-breaking investigations and analysis involved the reporting of climate policy and climate science in the media by Bacon, and a celebrated study of the reporting of the 2011 News of the World phone hacking scandal in Australian newspapers. More recently, key inquiries included media reporting of the cases of forensic patients, with a Background Briefing exposé for ABC Radio National (Bacon \& Nash, 2017).

Bacon has led by example in examining and pioneering ways that journalism itself 'might be regarded as research' in academic context through establishing research-based journalism projects (see for example her 2011 study for the ACIJ auditing how ten Australian mainstream newspapers reported on a tense political debate over carbon policy in the country. She found numerous examples of 'hostile' media campaigning against the policy rather than reporting and analysing it and also misrepresenting climate change in defiance of a global consensus (Bacon, 2011). Eventually, she and I established a 'Frontline' section in the New Zealand-based journal Pacific Journalism Review in 2012 to showcase examples of journalism-asresearch (Robie, 2015b). In the May edition that year, we published two investigative journalism articles with exegeses about nickel mining in New Caledonia and the Freeport gold and copper mine in Indonesia's most easternmost province Papua (Abplanalp, 2012; Gooch, 2012). Bacon followed this up in the next edition of PJR with a theoretical rationale for the new editorial section, explaining that the journal had always been concerned to link 'robust and informed journalism' with media research that contributed to social development in the broader community, the media industries and inside the academy (Bacon, 2012).

This provided an impetus for the publication of university-based radical and independent media. A Columbia Journalism Review analysis of the 'transformation' of American journalism flagged an era where the dominance of established and legacy news media and networks was rapidly giving way to a ruptured and widely dispersed gathering and distribution of news through digital media and connective media networks. The fundamental question being asked by the authors, Downie and Schudson, was that of how to counter the threat to independent reporting that had been providing 'information, investigation, analysis and community knowledge' in 


\section{David Robie}

both local and global affairs (Downie \& Schudson, 2009). Such questions have been similarly addressed by, among others, in New Zealand political economist Geoff Kemp, and in Australia journalism research methodology advocate Chris Nash in his 2016 book What is Journalism? and cultural studies theorist Graeme Turner in his 2016 book Reinventing the Media. Both titles were published in 2016.

Downie and Schudson (2009) acknowledged that many universities in the United States were publishing the reporting of student journalists 'on the states, cities, and neighbourhoods' where the campuses were located. Frequently, the student work in journalism classes and news services was supervised by professional journalists employed by the faculties. Sometimes the student work is published by the universities' own media, at other times it is published by industry media seeking to supplement their own coverage, occasionally for a publishing fee. Among the better known US university daily newspapers is the Columbia Missourian (www.columbiamissourian.com), which has been publishing since the University of Missouri journalism school was opened in 1908. The Graduate School of Journalism at the University of California at Berkeley with local news outlets and the Walter Cronkite School of Journalism at Arizona State University in Phoenix and its highprofile Cronkite News Service (cronkiteneww.jmc.asu.edu) are among others. Downie and Schudson note:

Universities are also becoming homes for independent nonprofit investigative reporting projects started by former newspaper and television journalists. Some are run by journalists on their faculties, while others, such as The Watchdog Institute at San Diego State University, are independent nonprofits that use university facilities and work with faculty and students. (Downie \& Schudson, 2009)

While this may seem rather encouraging for independent campus-based media, and Downie and Schudson cite many successful examples and models, there is also a downside to this development. Jonathan Peters has cautioned in the Columbia Journalism Review that at the time of writing at least four university newspaper advisers had been stripped from their roles or faced their positions being curbed or axed altogether (Peters, 2015). He warned that this development was raising concerns among independent media advocates about the survival of some university-based publications. 
"Two of the cases have prompted lawsuits, and one of the former advisers has filed a grievance. At one school, the entire journalism program was cancelled and funding to print the student newspaper was slashed" (Peters, 2015).

Peters cited Frank LoMonte, executive director of the Student Press Law Center, which provides legal and material support for student editors and journalists, as saying: "It's a perfect storm of financial stress for colleges and universities ... And the local conditions are ripe for censorship and retaliation" (as cited in Peters, 2015).

At the time of writing, the New Zealand media industry has claimed to be in dire straits, after failing to wrest a favorable verdict from the Commerce Commission on an application from the two largest newspaper chains in the country, NZ Media and Entertainment (NZME) and Fairfax Media, to merge (Commerce Commission, 2016). If they had succeeded in their bid to put 90 percent ownership of print media under the umbrella of a single company, the plurality of media in the country would have been seriously undermined with untold damage to representative democracy. The Commission declared in its ruling on 3 May 2017 that a merged identity would have had 'direct control of the largest network of journalists in the country', one employing more editorial staff than the next three largest mainstream media organizations combined. Including its radio network, the merged entity would have a 'monthly reach of 3.7 million New Zealanders': "This merger would concentrate media ownership and influence to an unprecedented extent for a well-established modern liberal democracy" (Commerce Commission, 2017).

According to one of New Zealand's leading investigative journalists, Nicky Hager, who co-authored the 2017 book Hit \& Run alleging a cover-up of an SAS atrocity in Afghanistan in 2010 that killed six civilians, including a three-year-old girl, and wounded 15, the previous two years had been a turning point for the media (Hager \& Stephenson, 2017). These years, he says, may be remembered as moment when New Zealand news media stopped being able to carry out their Fourth Estate function (Hager, 2017).

2015 was the year when TV3 slashed serious current affairs and investigative journalism. The same happened at Māori Television: two out of three major TV channels at once, both with a strong smell of political interference. The New Zealand Herald, which until recently, had the best array of columnists, merged its news with Newstalk ZB radio, cutting various critical commentators and replacing them on the Herald website with the opinions of talkback hosts. 2016 saw plans for the mega-merger of the two main private newspaper/media 


\section{David Robie}

companies, a further great, panicked rationalization. Government-friendly media celebrities increased in dominance. Clickbait was so ubiquitous that it was ceasing to be a pejorative term. (Hager, 2017)

This shrinking mainstream media plurality in New Zealand provides a context for examining publication of campus-based media based at AUT's Pacific Media Centre, where student and faculty editorial staff have successfully established an independent digital press over the past decade. I have been involved with four university-based journalism publications over two decades as key adviser/publisher in Papua New Guinea (Uni Tavur, 1993-1998); Fiji (Wansolwara, 1998-2002); and Aotearoa/New Zealand (Pacific Scoop, 2009-2015; Asia Pacific Report, 2016 onwards) (see Figure 1), and also with a publication in Australia (Reportage, 1996). I was also one of the two founding lecturers of Te Waha Nui and the associated News Production course at AUT during 2003-2007 and I written extensively about this experience elsewhere (Berney \& Robie, 2008; Robie, 2006).

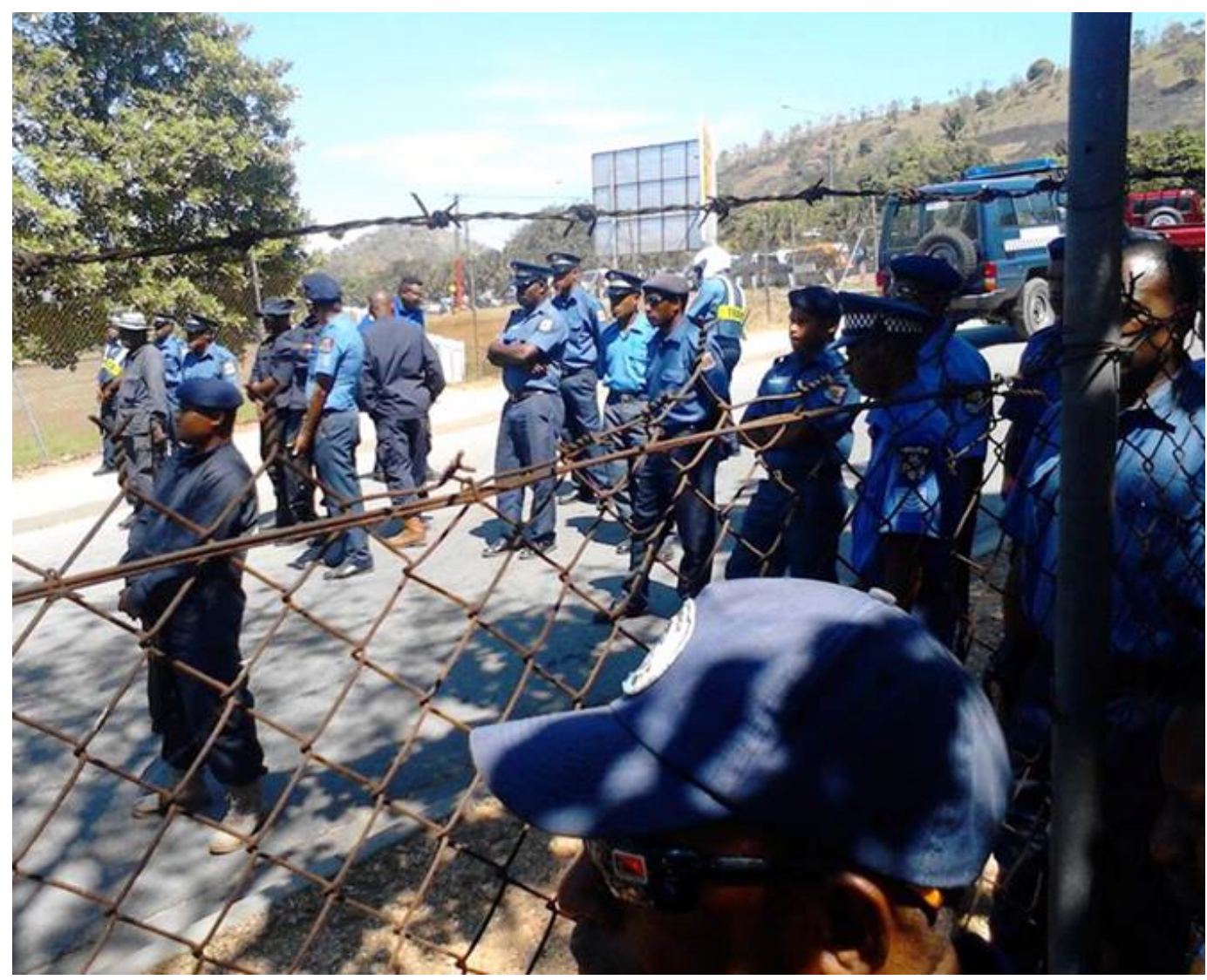

Figure 1. Papua New Guinea police blockading the entrance to the University of Papua New Guinea, where the award-winning Uni Tavur was published and where Asia Pacific Report has a network of correspondents.

(Source: Uni Tavur) 


\section{The Asia Pacific Report Publishing Ethos}

In mid-2007, the Pacific Media Centre Online was established as the umbrella website for AUT's Pacific Media Centre in providing independent research tools, publications and resources for the region (www.pmc.aut.ac.nz). It also initially became the publication outlet for students on the postgraduate Asia-Pacific Journalism Studies paper, established that year as the first course of its kind at any New Zealand university. The PMC Online website was closely associated with the Pacific Journalism Review research journal's website (www.pjreview.info) and the Pacific Media Watch monitoring service and database (www.pacmediawatch.aut.ac.nz) (Robie, 2014a).

Both the PMC and Scoop Media Ltd, collaborated to launch Pacific Scoop as a specialist news and analysis outlet covering the South Pacific region. It was also both an educational outlet and a publication open to contributing academics and journalists. Catering for this niche field was a collaborative effort of then Scoop coeditor Selwyn Manning and me. In August 2009, the partnership between the PMC and the Scoop Media group resulted in the launch of Pacific Scoop as a joint collaborative publication at the AUT Māori Expo. This was a rare development between an industry media group and an academic institution.

By late 2015, the media scape around Pacific Scoop had changed. Co-founder Selwyn Manning had resigned as co-editor in 2011 and concluded his role on Scoop Media's board in the same year. Through his new independent company, Multimedia Investments Ltd, Manning founded in 2012 security-intelligence analysis site 36thParallel.com, open-source intelligence sites ForeignAffairs.co.nz, LiveNews.co.nz, NewsKitchen.eu and de.Newskitchen.eu. In 2013, he co-founded the popular Daily Blog, which recruited an ever-growing stable of progressive and leftist columnists and commentators and collaborated with Radio Waatea to offer New Zealand's only daily current affairs television program, the half-hour Fifth Estate. In 2014, Manning founded and launched EveningReport.nz which combines reportage and analysis with public interest webcasting.

The Pacific Media Centre had by then started to seek a new platform. An active digital collaboration with Little Island Press publisher Tony Murrow to produce the microsite 'Eyes of Fire: 30 Years On', an extension of the 30th anniversary edition of my book, Eyes of Fire (Robie, 2015a) about the Rainbow Warrior bombing in July 1985, 


\section{David Robie}

was a key factor in the pioneering new venture. We produced a series of oral histories by some forty AUT journalism and television students. A subsequent meeting with Selwyn Manning confirmed our decision to press ahead with establishing Asia Pacific Report. Reflecting on the 2009 launch of Pacific Scoop, Manning argues that it was quite a successful effort at branding a niche service', but he cautioned that perhaps it benefitted strongly from being attached to Scoop (Selwyn Manning, personal communication with the author, 6 July 2016).

Multimedia Investments Ltd, the parent company to EveningReport.nz, owns or part owns a network of complementary news outlets, each occupying a specific niche, and cumulatively exporting more than 30,000 published items per month to global aggregation companies. The nonprofit joint venture between Multimedia Investments Ltd and the Pacific Media Centre's Asia Pacific Report plugs the website's 'Asia-Pacificrich' content into this network and enables it to achieve considerable reach, adding value to the readership potential to each item published (Figure 2). In May 2018, the public broadcaster Radio New Zealand announced a content sharing agreement with the Pacific Media Centre and Asia Pacific Report in recognition of them as a 'natural partner' in Asia-Pacific news and current affairs coverage (RNZ, 2018).

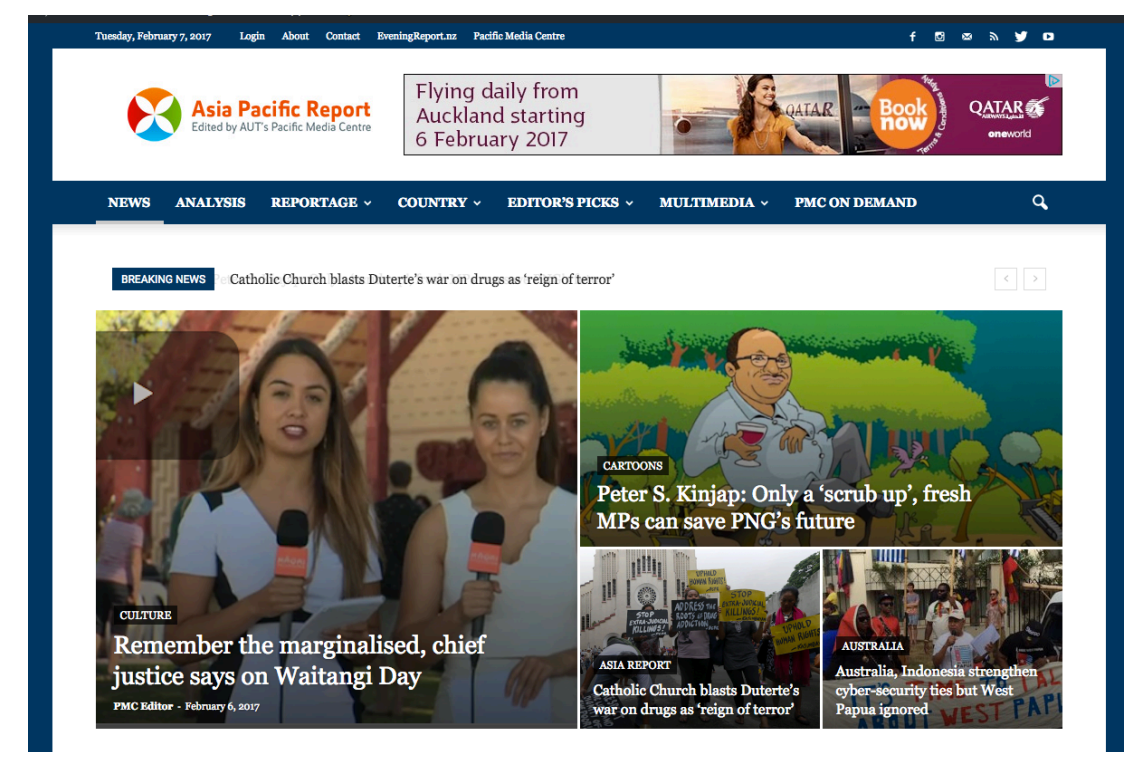

Figure 2. An Asia Pacific Report front page online featuring Waitangi Day; corruption in Papua New Guinea, the Catholic Church condemning Philippines President Duterte's 'reign of terror' which has already led to 7600 assassinations in seven months; and Australia and Indonesia discussing cyber-security but failing to address West Papua.

(Source: APR, 6 February 2017) 
Establishing this opportunity of reach and the opportunity to create a contemporary online environment where the PMC and AUT Asia-Pacific students develop their professional and political talents was a key factor driving Asia Pacific Report within a rich learning environment. Our website policy declared that the focus was students reporting on 'a range of Asia-Pacific issues ranging from climate change and the environment to education and health to politics, media, law social justice and sustainable business' (About Asiapacificreport.nz, n.d.). The New Zealand reportage is in partnership with students at the University of Santo Tomas, Philippines, and the University of the South Pacific, Fiji. The core objectives:

1. [Providing] an independent Asia-Pacific voice telling the untold stories

2. [Providing] an educational media resource boosting the quality on regional reporting

3. Addressing justice for the marginalized, and

4. Providing Asia-Pacific journalism internships

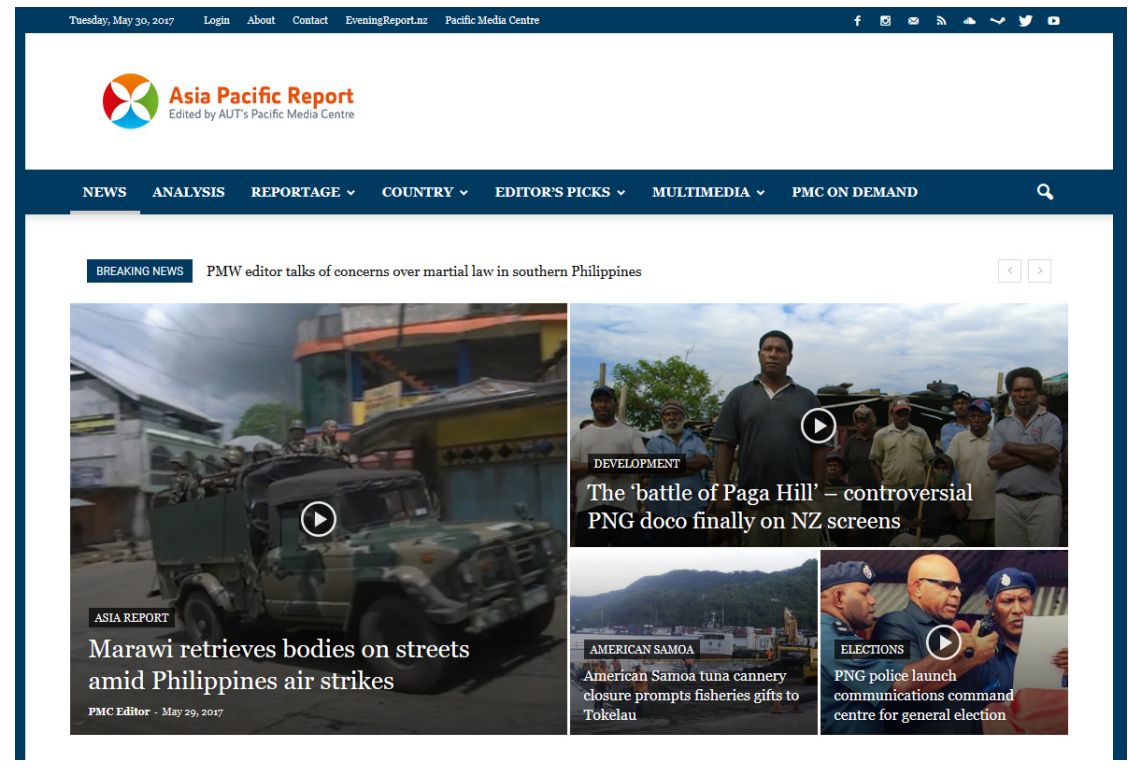

Figure 3. An Asia Pacific Report front page online featuring the Battle of Marawi City in Mindanao in the southern Philippines; a controversial 'battle of Paga Hill' indigenous land rights struggle documentary; closure of a cannery in American Samoa; and Papua New Guinea police opening a communications command centre for the June 2017 general election.

(Source: APR, 29 May 2017)

What does Asia-Pacific Report offer that had not already been part of Pacific Scoop? The new venture has a far stronger and more radical 'Asia-Pacific' content mix with wider and more relevant Asia content, especially human rights, with the occasional piece, usually analysis, that is truly global. In one year the website has climbed to a monthly audience of more than 23,000 . Among the more successful 


\section{David Robie}

audience reaches in the past eighteen months of publishing was during the Philippines presidential election on 9 May 2016 when Asia Pacific Report ran a live feed from Rappler in Manila (with the anchor page having 1786 views that day) (LIVE: \#PHVote2016, 2016). Between the 2006 and 2012 national census, the Filipino diaspora community in New Zealand more than doubled from 15,285 to 37,302. In 2013, 40,350 people claimed Filipino ethnicity (Story: Filipinos, n.d.). Asia Pacific Report has also run several insightful articles about the tough-talking president-elect Rodrigo Duterte. This was both before he was sworn in on June 30 and since then, as the number of 'war on drugs' extrajudicial killings has reached more than 7800 people and martial law has been declared on the southern island of Mindanao in the so-called 'Battle of Marawi City' against jihadist rebels (Robie, 2016a) (see Figure 3).

The largest audience for a single Asia Pacific Report story has been 7540 on 15 March 2017 about an attack outside a courtroom on a young woman reporter working for the state-run Fiji Broadcasting Corporation (Figure 4). Reporter Praneeta Prakash was 'shooting footage of a man sentenced in a corruption related case in Suva when a remand prisoner being escorted by police to the cell block threw a stone at her which struck her stomach' (Vacala, 2017). The assault took place under the gaze of police officers who did nothing.

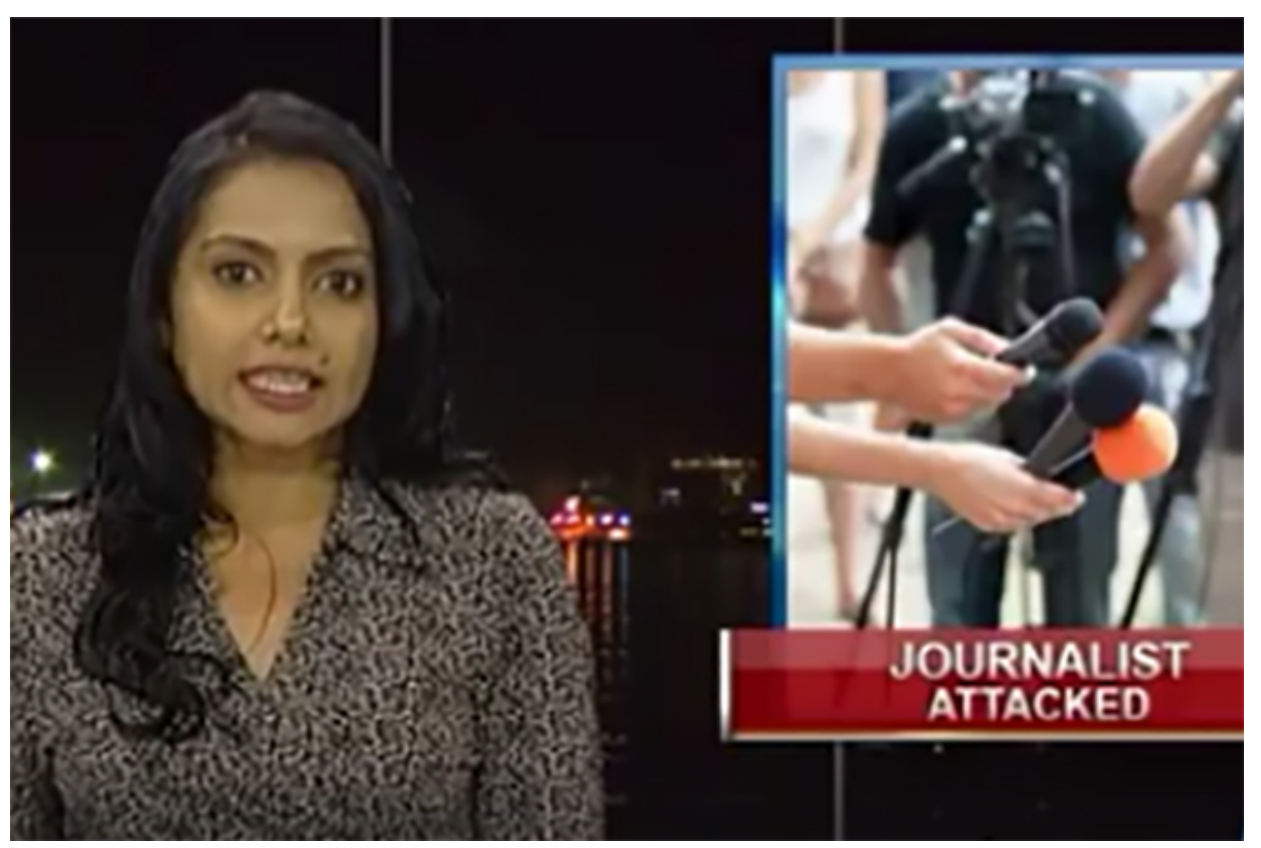

Figure 4. Presenter Amrita Sagar of the Fiji Broadcasting Corporation News narrates the attack on reporter Praneeta Prakash.

(Source: Asia Pacific Report embedded news bulletin, 15 March 2017) 


\section{Discussion of Case Studies}

The following sections sketch short case studies of some of the exemplar issues during Asia Pacific Report's start-up year. They are typical examples of coverage on the website and demonstrate issues that are rarely in the mainstream New Zealand media discourse, even when they have been adopted in a global media scape. Since the last week of January 2016 with the launch of Asia Pacific Report by Pacific Cooperation Foundation chairman Laulu Mac Leauanae, the website has projected a strong climate change and environmental focus.

\section{Case 1: February-March 2016: De Brum, Nuclear Zero Lawyers and Climate Change}

The website's first story to reach 2000 views, shortly after being launched, was an exclusive report about Marshall Islands Foreign Minister Tony de Brum and the Northern Pacific republic's legal team Nuclear Zero being nominated for a Nobel Peace Prize for their 'courageous step' in filing lawsuits against the nine nuclear nations (Archer, 2016). As highlighted in a new documentary by John Pilger, The Coming War with China, the United States tested 60 nuclear bombs in the Marshall Islands, 23 of them at Bikini Atoll, and 'vaporised' three islets (Pilger, 2016). They were nominated by the Oslo-based International Peace Bureau, which is dedicated to the vision of a world without war and is itself a Nobel Peace Laureate. In 2015, Tony de Brum was one of the four winners of the Right Livelihood Award, also known as the 'Alternative Nobel Prize'. The people of the Marshall Islands were joint recipients. As a nine-yearold boy, de Brum witnessed the 'greatest-ever Hellfire ignited by the USA' - the Castle Bravo bomb, one thousand times more powerful than the Hiroshima bomb and detonated in 1954 (de Brum, 2015). He has dedicated much of his life to 'banning all nuclear weapons and fighting global warming'. Condemning the existence of 16,000 nuclear warheads, he says: 'we are witnesses as nuclear nations modernize and expand their arsenals ... There can be no right of 'unlimited possession' (de Brum, 2015). De Brum and Nuclear Zero did not succeed in winning either the Nobel of the lawsuits, but they won a remarkable global moral victory (AFP, 2016).

Between February 15-17, Asia Pacific Report comprehensively covered the 'In the Eye of the Storm' climate change conference in Wellington, particularly through the work of a freelance journalist, Thomas Leaycraft, in collaboration with Scoop Media (Leaycraft, 2016). In April, the Pacific Media Centre dispatched two journalists, 


\section{David Robie}

TJ Aumua and Ami Dhabuwala, to Fiji in the mid-semester break to work with the University of the South Pacific's Centre for the Environment and Sustainable Development (PaCE-SD) to research and report on a 'Bearing Witness' climate change assignment. As part of this project, they visited a village, Daku, in the Rewa River delta and witnessed first-hand how the villagers have been empowered by adaptation strategies (Fiji Report-Bearing Witness, 2016). The project continued in April 2017 with Asia Pacific Report dispatching Kendall Hutt and Julie Cleaver to the remote Viti Levu island village of Tukuraki, which is being relocated by the government after being destroyed successively by two cyclones and a landslide (Hutt \& Cleaver, 2017).

\section{Case 2: Kilman Government vs Vanuatu Daily Post on Air Safety}

Meltek Sato Kilman, a francophone, was a compromise prime minister in Vanuatu in early 2016, having been elected in June 2015 barely a week after being sacked as foreign minister. Former prime minister Vanua'aku Pati Joe Natuman was ousted in a no-confidence vote, largely blamed on Cyclone Pam, which devastated the country in March, and the government's failure to respond decisively. The country depends heavily on its tourism industry, with at least 65 percent of gross domestic product earned through this sector. Less than a year after Cyclone Pam, Vanuatu and its troubled tourism industry faced a crisis over aviation safety. After the Vanuatu Daily Post reported a front page story on 27 January 2016 exposing a Port Vila international airport safety issue, caretaker Prime Minister Kilman accused the newspaper of bringing his 'name into disrepute', and of 'partisan bias' (Caretaker PM, 2016). Editorial director Dan McGarry rejected this attack and penned a fresh editorial:

... [T] he accusation that we have somehow politicised the issue is simply false. The entire piece is an argument against politicising this topic. Yes, Mr Kilman's government is hardly the only one guilty of playing political football with the lives of our travellers. We agree on that point. The key point in the editorial was:'Three different governments, three different plans. That's no way to run a country.' (McGarry, 2016)

Republishing this editorial as a news story in collaboration with McGarry meant that this item was the first on Asia Pacific Report to nudge 2000 views. Such interest indicated that this issue was important for the region and while New Zealand media only reported Air New Zealand pulling out its scheduled flights, Asia Pacific Report 
provided broader, more nuanced coverage about the politics and media freedom and freedom information behind the safety issues. Ten well-informed articles on the issue over the next few weeks concluded with a report on May 8 declaring that the Bauerfield Airport had been 'rehabilitated' and a 'new tourism era' was being ushered in (Vanuatu airport, 2016). The Asia Pacific Report coverage was thanks to collaboration with the Vanuatu Daily Post and contributions by citizen journalists and social media through Vanuatu Daily Digest.

\section{Case 3: May-June 2016: University Unrest in Papua New Guinea}

History was apparently repeating itself in Papua New Guinea during June 2016. Some international news media—not local—notably The Guardian Australia, reported on June 8 that four students had been killed when police opened fire on them at the University of Papua New Guinea (Davidson, 2016). This followed the deaths of three students in similar circumstances in 2001. However, the 2016 reported deaths were incorrect (Figure 4). While some 23 people-four critically-were reported wounded by hospital authorities, they all survived. In the six weeks leading up to the shootings, the hashtag \#UPNG4PNG became a 'hot' twitter theme as the country's universities mounted a series of peaceful protests and class boycotts seeking to force Prime Minister Peter 0'Neill to step down from office in the face of persistent allegations of corruption. The students cited 'multiple criminal investigations against him, attempts to shut down the police force's corruption unit, and poor fiscal management' (Pryke, 2016b). This climaxed when PNG police opened fire on a peaceful demonstration when they failed to arrest the Student Representative Council president Kenneth Rapa, and later at Unitech on June 25 when off-campus 'marauders' killed a student with bush knives (Kama, L., 2016). Students at the country's universities, particularly UPNG, were the latest in a 'long list of those in the firing line for denouncing the leadership of Papua New Guinea's seemingly impregnable Prime Minister Peter O’Neill' (Kama, B., 2016). The students wanted O'Neill to resign and also for the police commissioner not to suppress investigations into corruption allegations implicating the prime minister. The students had been on strike since the end of April until finally the frustrated UPNG administration abandoned the academic year and disbanded the SRC, stripping it of its campus authority (Aupong, 2016). 


\section{David Robie}

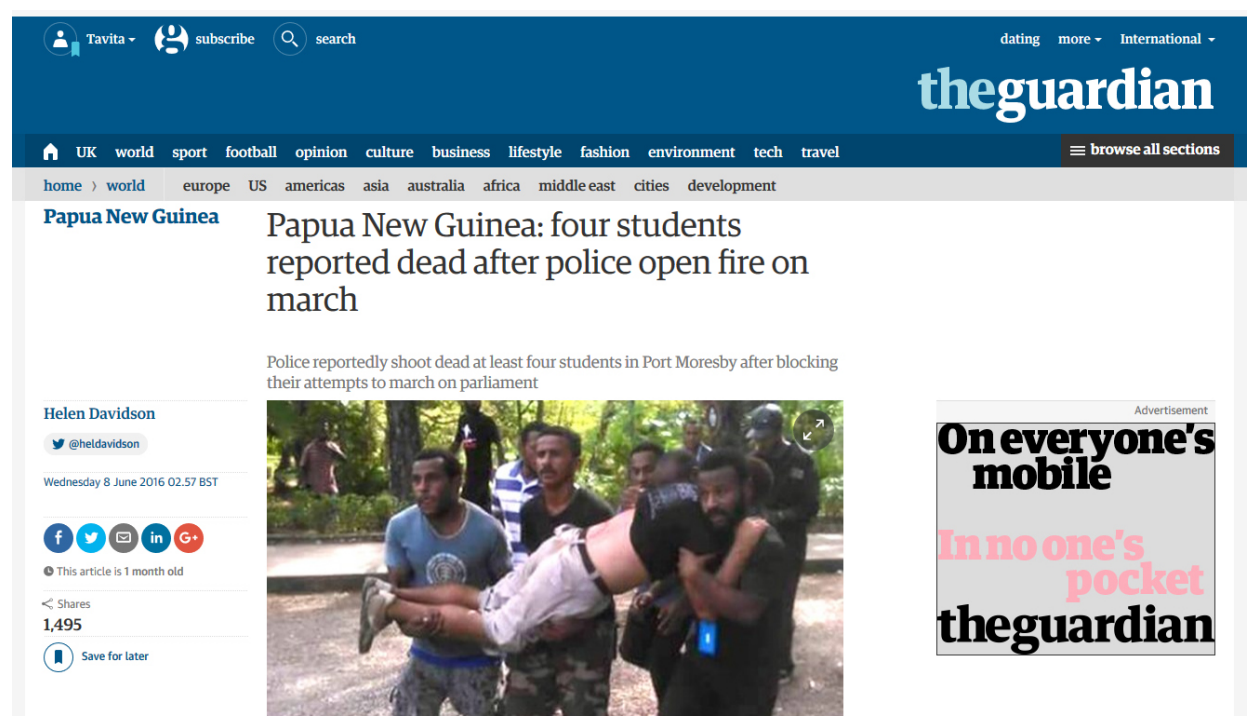

Figure 5: Helen Davidson's article in The Guardian wrongly headlined 'Papua New Guinea: four students reported dead after police open fire on march', 8 June 2016. This was widely rehashed in other news media.

(Source: The Guardian, 8 June 2016)

However, in spite of the students' persistent campaign, including mounting a lawsuit against the UPNG management, and their historical track record of being political dissidents, there was little chance that O'Neill would step down. In an analysis of the struggle in the Lowy Institute's The Interpreter and Café Pacific, Australian National University legal studies doctoral candidate Bal Kama assessed their strength. He noted how they had been a 'powerful tool for political activism on national issues' since Independence in 1975. In 1991, students had become embroiled in a 'violent protest against the government for increasing MPs' salary. Six years later, students teamed up with the PNG Defense Force to 'protest against the Sandline mercenaries in the Bougainville crisis'. They demanded the resignation of then Prime Minister Sir Julius Chan, who withdrew the mercenaries and resigned. In 2001, students protested against the privatization of state assets and a land mobilization programme (LMP) administered by Sir Mekere Morauta's government. While Mekere withdrew the policies, which had been part of a World Bank structural adjustment programme (SAP) (Kama, B., 2016), the success came at a severe political cost. Security forces were accused of having shot dead three students.

The PNG Constitution provides for the right to protest, to hold public assembly, and for freedom of expression. However, these are qualified rights, meaning they can be restricted if it appears that a protest would cause disharmony and instability. The laws were tightened up after the bloody outcome in the 2001 protest against Mekere's 
government when two young Uni Tavur student journalists gave testimony to the Commission of Inquiry (Wakus, 2001). The 2016 protests were essentially within university campuses because of the restrictions and the associated risks in taking to the streets. In the absence of reporting of the students versus O'Neill developments by New Zealand media (apart from Radio New Zealand Pacific), Asia Pacific Report extensively covered the unrest in collaboration with digital media, such as Loop PNG and PNG Today, and citizen journalists, including one senior academic staff member at UPNG who supplied us with regular quality images (Images: Students accused, 2016).

\section{Case 4: June 2016: Samoa Observer Front-page Suicide Controversy}

In Samoan language, the word fa'afafine includes the prefix 'Fa'a', meaning 'in the manner of', and fafine meaning 'woman' (Milner, 1966, p. 52). This 'third gender' is well-accepted in Samoan culture and they are traditionally trained from a young age to do 'women's daily work' in an Aiga (Samoan family group) (Danielsson et al., 1978). On 19 June 2016, the Sunday Samoan edition of the Samoan Observer reported the death of a young Samoan transgender woman in Apia on the front page. The newspaper showed a full-length image of 20-year-old Jeanine Tuivaiki's lifeless body hanging from the rafters in a central Apia church hall. In the accompanying news story, the newspaper misgendered the tragic young woman. Mounting public anger over the newspaper's publishing action spread to New Zealand with a prominent trans-rights campaigner, Phylesha Brown-Acton, condemning the coverage "I am absolutely disgusted by the Samoa Observer and their front page photo of a young fa'afafine woman,' she said, describing the reporting as 'completely inappropriate and disrespectful" (Gato'aitele Savea Sano Malifa, 2016).

Where is the respect for this young person and her family? The use of such an image to sell newspapers is the lowest form of sales tactics and the editor and the reporter should be held accountable for such degrading journalism. (Ibid.)

The Samoa Observer followed up with an initial front page apology on July 20 headed 'And if you're offended by it still, we apologise' that critics regarded as selfjustification, and this prompted further widespread criticism on social media. Finally, editor-in-chief Gotoa'itele Savea Sano Malifa wrote a personal apology-he had not been involved in the editorial decision to publish the front page image and story-to Samoa Observer readers published in the July 21 edition. 'The truth is that last week, 


\section{David Robie}

we made a sad mistake when we published a story on the late Jeanine Tuivaiki, on the front page of the Sunday Samoan. We now accept that there has been an inexcusable lapse of judgment on our part, and for that we are sincerely regretful (Samoa Observer, 2016).

However, this sincere apology, along with Savea also pointing out that the newspaper had been a strong supporter of the rights of the fa'afafine over many years, did not stem the deluge of hostile letters and social media attacks. This situation prompted Kalafi Moala, chief executive of the Taimi 'o Tonga group and deputy chair of the Pasifika Media Association (PasiMA), to pen his own personal message in an attempt to bring some perspective back into the debate: 'A brother has made a terrible mistake. He has, however, taken responsibility for it and has apologised. Those of us who are offended need to offer forgiveness in the spirit of Pacific compassion, and move on.'

Moala also noted he had known Savea for almost 30 years, and described him as one of the most professional and enduring journalists in the Pacific. Savea had also been successful in building a news organisation, and a daily publication that had 'made all of us Pacific people proud'. Samoa Observer also has a code of ethics, and Savea is regarded as a 'passionate advocate' for strong news media ethics. Moala added:

Reaction to the Sunday Samoan report has been largely fair, and reasonable. Media is often the harshest critic of itself, but criticism is usually left with a closeended condemnation without any solutions. (Kalafi Moala, 2016)

Asia Pacific Report had no solutions either, but rather than joining the 'blame game' that many media indulged in, stirring even greater offence, this news website and its sister project, Pacific Media Watch, attempted to treat the editorial mistake as a learning experience and to embed constructive video resources and links available to Pacific journalists (Figure 6). Pasifika media can play a key role in leading 'safe messaging' about reporting suicide to Pacific communities. In partnership with Pasifika media in February (Le Va, 2016), launched the 'Pasifika media guidelines for reporting suicide in New Zealand', a whiteboard video providing an overview of the guidelines. The guideline can be downloaded from Le Va's website (www.leva.co.nz). Pasifika journalist Sandra Kailahi and twenty-three Pasifika media organisations contributed to co-developing the guidelines. 


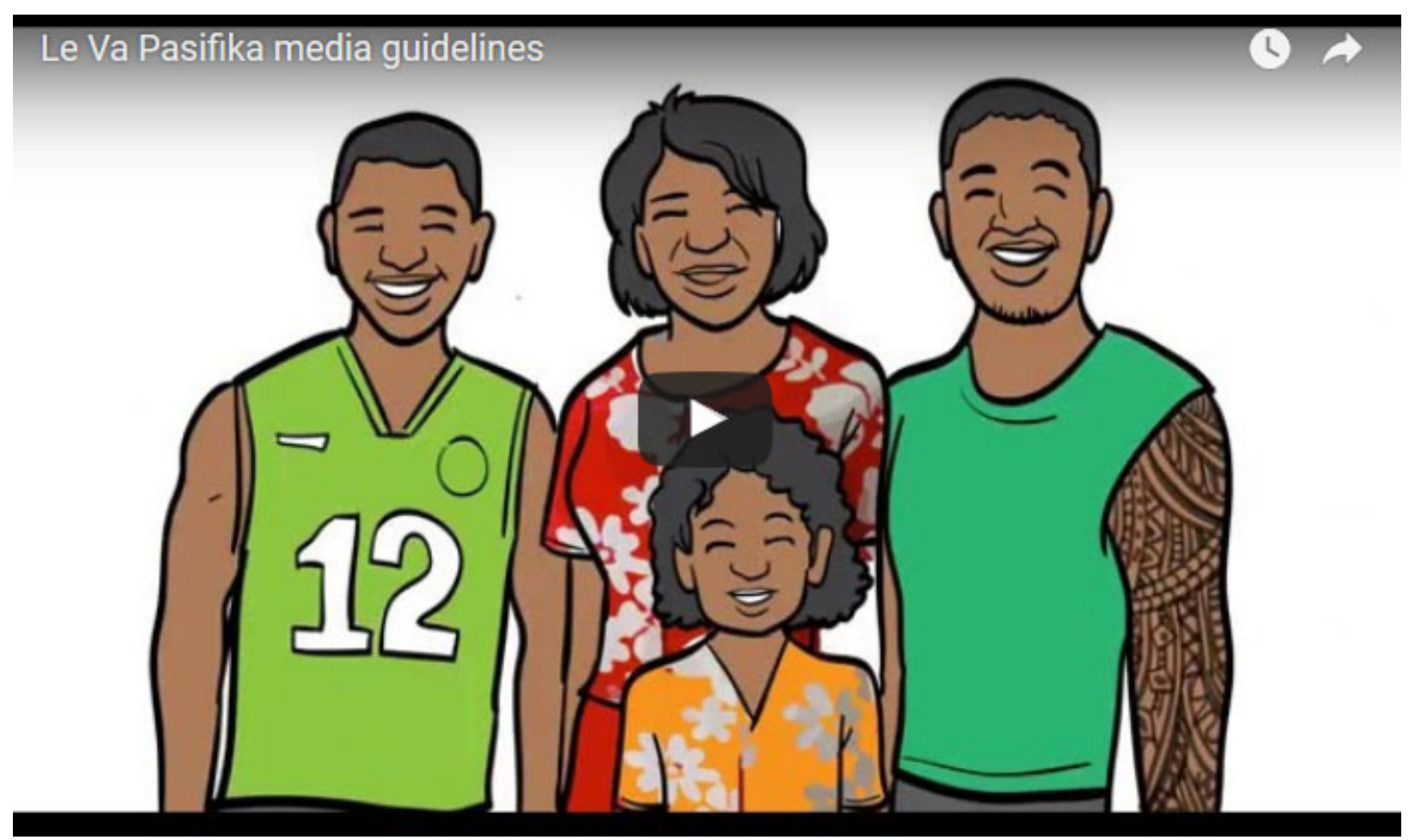

Figure 6: Le Va's Pasifika media guidelines 'whiteboard' video embedded in Asia Pacific Report's articles related to the Samoa Observer transgender suicide controversy, June 2016.

(Source: Asia Pacific Report, June 2016)

\section{Conclusion}

Few genuinely independent newspapers, especially progressive ones, exist in in New Zealand. For journalism educators, this makes it difficult for course facilitators to point to successful alternative publishing models in an Antipodean context. However, after the initial success of Pacific Scoop over six years, Asia Pacific Report has outstripped its predecessor in both audience reach, content and quality in just over a year. Analyst and commentator Keith Jackson wrote on his authoritative PNG Attitude website that Asia Pacific Report was making a contribution to the region at a time when key strategic issues at stake. These included great power rivalry between China and the United States, climate change, minerals and agriculture, human development and a stable South Pacific area whose component nations could collaborate, share and prosper.

Considered against such a backdrop, and the overall failure of news media to pay much attention to this area, Asia Pacific Report offers an invaluable and independent source of news and information ... And Asia Pacific Report practises what it preaches. (Jackson, 2017) 


\section{David Robie}

Many issues that impact on Polynesia often have parallels in Melanesia and Southeast Asia. Asia Pacific Report has been able to embrace, advocate, and report on the entire region, wherever the need for reportage and a radical perspective arises. Significant relationships have been established between the Pacific Media Centre and new media outlets in Southeast Asia. As Manning argues, 'An impressive number of students have benefited from international internships in this sector. Asia Pacific Report reflects this in its digital DNA' (Manning, 2016).

However, how truly sustainable is this independent model? A campus-based publication of this not only thrives, but depends, on its pool of creative, dedicated and talented students. In terms of actual funding, a current postgraduate student or recent graduate, preferably with an Asia-Pacific heritage, is employed as a contributing editor for between ten and twenty hours a week. Funding for this role is shared between the university and external grants; this is supplemented with royalties from databases and sale of research books and publications produced by the Centre. It would be an ideal project for a sponsorship from a foundation.

Unlike most media in New Zealand that have a limited international focus, Asia Pacific Report actually focuses on media coverage and analysis of this region with an impact factor within New Zealand. The risk factor is also much greater, as addressed by Joel Simon while discussing the problem of 'democratators' and the 'illusion of democracy' in the introduction to this article. The AUT Asia Pacific Journalism Studies postgraduate paper is the only international studies course of its kind in New Zealand. In spite of the former National-led government's policy to invest in Southeast Asian political or social capital as well as business (hence funding being provided for the establishment of a NZ Institute of Pacific Research in early 2016 and a proposal to establish a comparable Southeast Asian Studies centre of excellence in 2017), there is little interest in mainstream New Zealand media. The Asia New Zealand Foundation has established an Asian Media Centre to provide resources for New Zealand media and AUT University has become the only tertiary institution to establish an Indonesia Centre, which has fostered the introduction of Bahasa Indonesia language courses and is encouraging better media coverage. The public broadcaster Radio New Zealand Pacific provides excellent coverage of the micro-states of the region, but Asia is not actually part of its brief. Developing neighbour Timor-Leste, which has strong ties with the Pacific as well as with Asia, is also not part of RNZ Pacific's coverage zone. 
The Asia Pacific Report initiative sees itself as strategically positioning itself as a primary provider of content-both text and multimedia for the region, especially where human rights and peace journalism are concerned. Indonesia has frequently figured among the top five audiences on Asia Pacific Report (usually behind New Zealand, Australia, Papua New Guinea and the United States), especially at times of strong West Papuan coverage. At other times, Fiji, Papua New Guinea or Vanuatu might rank in the top five. In one month (May 1916, at the height of the student protests against Prime Minister O’Neill), Papua New Guinea was top.

The venture is unique in the New Zealand mediascape and over time it should contribute to raising issues of social justice and providing a broader, more progressive media education in the context of Pacific coups, civil war, climate change, development, human rights and neo-colonialism. It is a nonprofit model that can be replicated elsewhere. Increasingly, in the Trump era of 'war on media' it is vital to have publication brands that can be trusted. University media schools have a crucial role to play in this.

\section{Acknowledgements}

The author has initiated and developed independent student-driven progressive press and online Asia-Pacific projects in Australia, Fiji, New Zealand and Papua New Guinea for more than two decades. He would like to acknowledge colleagues involved in the various projects, including Selwyn Manning of EveningReport.nz, Dr Shailendra Singh of the University of the South Pacific, and Dr Philip Cass, of Auckland, New Zealand. In addition, he would like to thank contributing postgraduate students on the Pacific Media Watch independent news project over the past decade, which has included Indonesia and the Philippines: Taberannang Korauaba, Josephine Latu, Alex Perrottet, Daniel Drageset, Anna Majavu, Alistar Kata, TJ Aumua and Kendall Hutt.

\section{References}

About Asiapacificreport.nz (n.d.). Asia Pacific Report. Retrieved from http://asiapacificreport.nz/about/

Abplanalp, K. (2012). 'Blood money': A NZ investigative journalism case study. Pacific Journalism Review, 18(1), 128-147. 


\section{David Robie}

AFP (2016, October 6). Marshall Islands nuclear arms lawsuit thrown out by UN's top court. Agence France-Presse. Retrieved from https://www.theguardian.com/world/2016/oct/06/marshall-islands-nucleararms-lawsuit-thrown-out-by-uns-top-court

Archer, C. (2016, February 2). De Brum, Nuclear Zero lawyers nominated for Nobel Peace Prize. Asia Pacific Report. Retrieved from http://asiapacificreport.nz/2016/02/02/de-brum-nuclear-zero-lawyersnominated-for-nobel-peace-prize/

Aupong, S. (2016, July 5). UPNG abandons 2016 academic year, suspends student body'. Asia Pacific Report. Retrieved from http://asiapacificreport.nz/2016/07/05/upng-abandons-2016-academicyear-suspends-student-body/

Bacon, W. (2012). An innovative direction in academic journalism. Pacific Journalism Review, 18(2), 153-165.

. (2011, December 1). Carbon pricing policy in the media. The Conversation. Retrieved from http://theconversation.com/carbon-pricing-policy-in-themedia-3746

(2006). Journalism as research? Australian Journalism Review, 2(2), $147-$ 157.

Bacon, W., and Nash, C. (2017). An investigative legacy. Pacific Journalism Review, 23(1), 2017, 6-11.

Berney, J., \& Robie, D. (2008). Don't publish and be damned: An advocacy media case study. Global Media Journal, 2(1). Retrieved from www.hca.westernsydney.edu.au/gmjau/archive/iss1_2008/bernie_robie.html

Bradner, E. (2017, January 23). Conway: Trump White House offered 'alternative facts' on crowd size'. CNN Politics. Retrieved from http://edition.cnn.com/2017/01/22/politics/kellyanne-conway-alternativefacts/

Caretaker PM slams Vanuatu Daily Post for outspoken airport editorial (2016, January 30). Pacific Media Watch 9564 in Asia Pacific Report. Retrieved from http://asiapacificreport.nz/2016/01/30/caretaker-pm-slams-vanuatu-dailypost-for-outspoken-airport-editorial/ 
Commerce Commission New Zealand (2016, November 8). Commission proposes to decline NZME/Fairfax merger. Retrieved from http://comcom.govt.nz/thecommission/media-centre/media-releases/detail/2016/commissionproposes-to-decline-nzmefairfax-merger

Commerce Commission New Zealand (2017, May 3). Commission declines NZME/Fairfax merger. Retrieved from http://comcom.govt.nz/thecommission/media-centre/media-releases/2017/commission-declinesnzmefairfax-merger/

Danielsson, B., Danielsson, M-T., \& Pierson, R. (1978). Polynesia's third sex: The gay life starts in the kitchen. Pacific Islands Monthly, 49, 10-13.

Davidson, H. (2016, June 8). Papua New Guinea: Four students reported dead after police open fire on march. The Guardian Australia. Retrieved from www.theguardian.com/world/2016/jun/08/papua-new-guinea-police-shootat-students-during-march

de Brum, T. (2015, October 28). Tony de Brum: The nuclear-free future award. Nuclear-Free-Future.com. Retrieved from http://www.nuclear-freefuture.com/en/laureates/laureates/tony-de-brum/

Downie, L., \& Schudson, M. (2009, November/December) The reconstruction of American journalism. Columbia Journalism Review. Retrieved from http://archives.cjr.org/reconstruction/the_reconstruction_of_american.php

Fiji Report-Bearing Witness (2016). Pacific Media Centre on Storify. Retrieved from https://storify.com/pacmedcentre/fiji-report-bearing-witness-2016

Gooch, N., Background to 'Sulphate Sunrise'-investigating New Caledonia. Pacific Journalism Review, 18(1), 2012, 148-170.

Gato'aitele Savea Sano Malifa. (2016, July 21). Apology to our readers. Samoa Observer Editorial. Retrieved from www.sobserver.ws/en/21_06_2016/local/7674/Apology-to-our-readers.htm

Hackett, R. A., Forde, S., Gunster, S., \& Foxwell-Norton, K. (Eds.) (2017). Journalism and climate crisis: Public engagement, media alternatives, London, UK: Routledge Hager, N. (2017). The crisis is all around us, and so are the solutions. In E. Johnson, G. Tiso, S. Illingworth and B. Bennett (Eds.), Don't dream it's over: Reimagining journalism in Aotearoa New Zealand. Christchurch, NZ: Freerange Press. 


\section{David Robie}

Hager, N., \& and Stephenson, J. (2017). Hit \& Run: The New Zealand SAS in Afghanistan and the meaning of honour. Nelson, NZ: Potton \& Burton.

Hutt, K., \& Cleaver, J. (2017, May 9). Destruction and construction-Tukuraki's lonely story of survival. Asia Pacific Report. Retrieved from https://asiapacificreport.nz/2017/05/09/destruction-and-constructiontukurakis-lonely-story-of-survival/

Images: Students accused of setting cars on fire at UPNG security base [Citizen journalist gallery]. (2016, June 23). Asia Pacific Report. Retrieved from http://asiapacificreport.nz/2016/06/23/students-accused-of-setting-cars-onfire-at-upng-security-base/

Jackson, K. (2017, July 5). A news website that leads the way in Pacific journalism. PNG $\begin{array}{llll}\text { Attitude } \quad \text { [Weblog]. } & \text { Retrieved }\end{array}$ http://asopa.typepad.com/asopa_people/2017/07/a-news-website-thatleads-the-way-in-pacific-journalism.html

Juffa, G. (2017, July 2. Why these PNG elections are taking us towards dictatorship. Asia Pacific Report. Retrieved from https://asiapacificreport.nz/2017/07/02/garyjuffa-why-these-png-elections-are-taking-us-towards-dictatorship/

Kalafi Moala: A word on the Samoa Observer suicide report (2016, June 27). Asia Pacific Report. Retrieved from http://asiapacificreport.nz/2016/06/27/kalafi-moalaa-word-on-the-samoa-observer-suicide-report/

Kama, B. (2016, May 23). Standoff in PNG: Students take on Prime Minister Peter O’Neill. Café Pacific [Weblog]. Retrieved from http://cafepacific.blogspot.co.nz/2016/05/standoff-in-png-students-take-onprime.html

Kama, L. (2016, June 9). 'They shot at us like we're trying to rob a bank,' says UPNG student leader. Asia Pacific Report. Retrieved from http://asiapacificreport.nz/2016/06/09/they-shot-at-us-like-were-trying-torob-a-bank-says-upng-student-leader/; See also 'Unitech student dies after PNG attack, campus buildings set ablaze', Asia Pacific Report, 26 June 2016, retrieved from http://asiapacificreport.nz/2016/06/26/unitech-student-dies-in-pngattack-campus-buildings-set-ablaze/

Kemp, G. (2013, August 29). The Fourth Estate - can journalism really deliver on its promises? Pacific Media Centre Online. Retrieved from 
www.pmc.aut.ac.nz/articles/fourth-estate-can-journalism-really-deliver-itspromises

Kolhatkar, S. (2017, February 10). Fake news and Donald Trump's war on truth. Common Dreams. Retrieved from http://www.commondreams.org/views/2017/02/10/fake-news-and-donaldtrumps-war-truth; See also European Federation of Journalists (2017, March 29). How media are fighting fake news and disinformation. Europeanjournalists.org. retrieved from http://europeanjournalists.org/blog/2017/03/29/how-media-are-fightingfake-news-and-disinformation/

Leaycraft, T. (2016, February 18). Paris climate summit 'positive - but not enough for Pacific', says SPREP. Asia Pacific Report. Retrieved from http://asiapacificreport.nz/2016/02/18/paris-climate-summit-positive-butnot-enough-for-pacific-says-sprep-chief/

Le Va, (2016). FLO: Suicide prevention for Pacific communities. [Multimedia resource]. Retrieved from www.leva.co.nz/resources

Lingao, E. (2010, December 28). Maguindanao massacre: One year after. In The Maguindanao chronicles: Reports on politics, murder, and the quest for justice. Manila: Philippine Center for Investigative Journalism (PCIJ).

LIVE: \#PHVote2016 elections coverage by Rappler today (2016, May 9). Asia Pacific Report. Retrieved from http://asiapacificreport.nz/2016/05/09/live-phvote2016-elections-coverage-today-may-9/

McGarry, D. (2016, January 30). Vanuatu airport crisis: Daily Post hits back on safety. Asia Pacific Report. Retrieved from http://asiapacificreport.nz/2016/01/30/vanuatu-airport-crisis-the-price-ofpolitics-continued/

Manning, S. (2016, July 6). Personal communication

Milner, G. (1966). Samoan-English dictionary. Fa'afine entry.

Nash, C. (2016). What is journalism? The art and politics of a rupture. New York, NY, \& London, UK: Routledge.

Peters, J. (2015, June 22). Removal of faculty advisers' sparks concern about independence of student publications. Columbia Journalism Review. Retrieved 


\section{David Robie}

from

www.cjr.org/united_states_project/faculty_advisers_removed_concerns.php Pilger, J. (2016). The coming war on China. Dartmouth Films [Documentary feature film]. Retrieved from https://www.youtube.com/watch?v=G3hbtM_NJ0s

Pryke, J. (2016a, July 25). How the gloss came off PNG'S PM Peter O'Neill. The Interpreter. Retrieved from https://www.lowyinstitute.org/theinterpreter/how-gloss-came-pngs-pm-peter-oneill

Pryke, J. (2016b, June 8). Papua New Guinea's students have a point. Peter O’Neill should talk to them, not send police. The Guardian Australia. Retrieved from https://www.theguardian.com/commentisfree/2016/jun/08/papua-newguineas-students-have-a-point-peter-oneill-should-talk-to-them-not-sendpolice

RNZ (2018). RNZ content partnership with Pacific Media Centre. Radio New Zealand media statement. Retrieved from https://www.radionz.co.nz/media/116

Robie, D. (2016a, July 9). Duterte's tough stance, impunity big challenges for media in Philippines. Asia Pacific Report. Retrieved from http://asiapacificreport.nz/2016/06/28/dutertes-tough-stance-impunity-bigchallenge-for-media-in-philippines/ (2016b). 'Unfree and unfair'?: Media intimidation in Fiji's 2014 elections. In S. Ratuva and S. Lawson (Eds.), The people have spoken: The 2014 elections in Fiji (pp. 83-107). Canberra, ACT: Australian National University. Retrieved from http://press-files.anu.edu.au/downloads/press/p337333/pdf/ch052.pdf (2015a). Eyes of fire: The last voyage of the Rainbow Warrior. Auckland, NZ: Little Island Press. (Original edition published in 1986 by Lindon Books.) - (2015b). Advocating journalism practice-as-research: A case for recognition in the New Zealand PBRF context. Asia Pacific Media Educator, 25(1), 62-73. doi: $10.1177 / 1326365 X 15575591$

. (2015c). The struggle for media freedom amid jihadists, gaggers and 'democratators' [Review of the book The new censorship: Inside the global battle for media freedom by Joe Simon]. Pacific Journalism Review, 21/2, 197-199.

(2014a). Pacific Media Watch: Beyond parochial news. Media Asia, 41/3, 2014, 220-226, doi: 10.1080/01296612.2014.11690019 
. (2014b). Don't spoil my beautiful face: Media, mayhem and human rights in the Pacific. Auckland, NZ: Little Island Press.

. (2012). Independent journalism in the South Pacific: Two campus-based media case studies in Fiji and New Zealand. Global Media Journal, 6, 2012. Retrieved from http://aut.researchgateway.ac.nz/handle/10292/4579

. (2006). An independent student press: Three case studies from Fiji, Papua New Guinea and Aotearoa/New Zealand. Asia Pacific Media Educator, 17, 21-40. . (2004a). Mekim Nius: South Pacific media, politics and education. Suva, Fiji: University of the South Pacific Book Centre.

. (2004b). Ross Stevens and Uni Tavur A Kiwi publishing legacy among wantoks. Pacific Journalism Review, 10(2), 153-170.

. (2003). Cyberspace democracy: Freedom of speech dilemmas in Pacific journalism education, UTS Law Review, 9/5, 131-149. Retrieved from http://www.austlii.edu.au/au/journals/UTSLawRw/2003/9.html

Romano, A. (2011). International journalism and democracy: Civic engagement models from around the world. New York, NY, \& London, UK: Routledge.

RSF (2018, April 25): Hatred of journalism threatens democracies, Reporters Without Borders (RSF). Retrieved from https://rsf.org/en/rsf-index-2018-hatredjournalism-threatens-democracies

Shaw, I. S. (2011). Human rights journalism: A critical conceptual framework of a complementary strand of peace journalism. In I. S. Shaw, J. Lynch and R. A. Hackett (Eds.), Expanding peace journalism: Comparative and critical approaches. Sydney, NSW: Sydney University Press.

Simon, J. (2015). The new censorship: Inside the global battle for press freedom. New York, NY: Columbia.

Spongberg, M. (2017, March 28). Closure of the Australian Centre for Independent Journalism [Intranet email]. Faculty of Arts and Social Sciences, University of Technology, Sydney.

Story: Filipinos (n.d.). The encyclopedia of New Zealand. Retrieved from www.teara.govt.nz/en/filipinos/page-1

Sunday Samoan condemned for 'disgusting, degrading' reporting of death (2016, June 25). Pacific Media Watch 9705 in Asia Pacific Report. Retrieved from 


\section{David Robie}

http://asiapacificreport.nz/2016/06/20/sunday-samoa-condemned-fordisgusting-degrading-reporting-of-death/

Turner, G. (2016). Re-inventing the media. New York, NY; \& London, UK: Routledge.

Vacala, K. (2017, April 4). Attack on FBC reporter outside court stirs Fiji media $\begin{array}{llll}\text { protests. Asia Pacific Report. } & \text { Retrieved from }\end{array}$ http://asiapacificreport.nz/2017/03/15/attack-on-fbc-reporter-outsidecourt-stirs-fiji-media-protests/

Vanuatu airport runway repairs usher in new tourism era. (2016, May 8). Asia Pacific Report. Retrieved from http://asiapacificreport.nz/2016/05/08/vanuatuairport-runway-repairs-usher-in-new-tourism-era/

Wakus, W. (2001). 'I couldn't stop crying': The Uni Tavur Testimony1. Pacific Journalism Review: Te Koakoa, 7(1), 127-128. Retrieved from https://doi.org/10.24135/pjr.v7i1.717 